\title{
Study of arsenic genotoxicity in a freshwater fish (Channa punctatus) using RAPD as molecular marker
}

\section{Deepak K Jha}

Patna University

Niti Yashvardhini

Patna Women's College

\section{Saurav Bhattacharya}

Techno India University

Kumar Sayrav

VKSU: Veer Kunwar Singh University

Amod Kumar

Kirori Mal College

Parimal Khan ( $\nabla$ parimal_khan@yahoo.co.in )

Patna University https://orcid.org/0000-0002-6936-414X

\section{Research Article}

Keywords: Arsenic, Channa punctatus, Genotoxicity, polymerase chain reaction (PCR), randomly amplified polymorphic DNA (RAPD), molecular marker

Posted Date: April 22nd, 2021

DOI: https://doi.org/10.21203/rs.3.rs-413515/v1

License: (c) (1) This work is licensed under a Creative Commons Attribution 4.0 International License. Read Full License 


\section{Abstract}

Arsenic, the proven genotoxic carcinogen in humans, is a groundwater contaminant of global concern. The present work investigates the applicability of randomly amplified polymorphic DNA (RAPD) as molecular marker to demonstrate arsenic genotoxicity in the freshwater fish, Channa punctatus. Fish specimens, segregated into three groups, were exposed to 10,50 and $500 \mathrm{\mu gL}^{-1}$ of arsenic respectively for 20 consecutive days. DNA extracted from same specimens of each group before and after exposure was amplified by polymerase chain reaction (PCR) using single arbitrary primers. Marked changes in RAPD profiles of fish DNA were observed upon exposure to arsenic compare to RAPD profiles of their preexposure state, resulting from loss or gain of certain bands. Altogether a total of 41 loci were amplified with 37-41 bands in each group. Band 1 of pre-exposure state was lost in all post-exposure samples while bands 4, 6 and 7 appeared as new bands after exposure to arsenic. The changes in the RAPD banding patterns upon exposure to arsenic reflect alterations in fish DNA. The RAPD bands, therefore, appeared as potential markers, capable of revealing the genotoxicity induced by arsenic in this piscine model.

\section{Introduction}

Arsenic is a toxic environmental contaminant and group-l human carcinogen [1] which ranks first in the Priority List of Hazardous Substances [2]. According to a recent estimate, over 94 million to 220 million people in 70 countries are exposed to harmful levels of inorganic arsenic through the uses of groundwater as drinking water that affects the human population with adverse outcomes including cancers [3-5]. Moreover, inorganic arsenicals are proven genotoxic carcinogens [6]and their genotoxic effects have been reported in both humans and experimental animals using cytogenetic markers [7-11].

Advances in toxicogenetics have led to the application of molecular markers, including those based on polymerase chain reaction (PCR), in the assessment of genotoxicity. In PCR based techniques, multiple amplicons of variable length are produced when a single oligonucleotide primer anneals to several regions of genomic DNA [12]. Such amplicons appear as fingerprints of randomly amplified polymorphic DNA (RAPD) upon agarose gel electrophoresis which are now used extensively as molecular marker to demonstrate damage/alterations in DNA induced by environmental contaminants [13-19]

Atienzar et al. [14] observed that changes in the patterns of RAPD reflected toxicological insults to DNA that ranged from single base substitutions to complex chromosomal aberrations. In many other observations, RAPD assay successfully manifests DNA alterations in fish induced by DNA damaging agents $[20,16,21]$. It appears to be a rapid screening assay at molecular level that also complements other well established techniques of genotoxicity assessment including micronucleus and comet assay $[15,22,16]$.

For the monitoring of genotoxic agents, Channa punctatus (among the non-mammalian organisms) has emerged as reliable and excellent piscine model which appears to be more sensitive to contaminants in 
water because of its various ecotoxiological charecteristics [23-29]. The present work was an attempt to demonstrate arsenic induced DNA damage/alterations by comparing the RAPD profiles of the specimens of freshwater fish, Channa punctatus, obtained before and after exposure to arsenic.

\section{Materials And Methods}

\section{Collection of fish specimens}

The healthy and adult specimens of fish Channa punctatus Bloh (Family; Channidae; order: Perciformes) were collected from local ponds having negligible arsenic content (below detection level) in their waters. The arsenic content of pond waters was estimated by the technique of flow injection hydride generation atomic absorption spectrometry (FI- Hg-AAS) using an atomic absorption spectrometer (AAS-Varian AA140; Agilent, USA) [30]. This technique was preferred since hydride generation mode can detected the level of arsenic upto as low as $1 \mathrm{\mu gL}^{-1}$. For quality control, the standard reference material and reagents blank supplied from National Institute of Standards and Technology (NIST, USA) was used. Fish specimens, each weighing 25-30 g and measuring $12-15 \mathrm{~cm}$ in length, were given prophylactic treatment of $0.05 \% \mathrm{KMnO}_{4}$ solution for two min to prevent dermal infections, and were acclimatized for 15 days under controlled laboratory conditions. They were fed with fish feed and small pieces of boiled egg at $5 \%$ of their body weight.

\section{Exposure level of test substance}

Fish specimens were segregated into three groups $\left(\left(T_{1}, T_{2}\right.\right.$ and $T_{3} ;$ Table 1$)$ where each group had 18 specimens. Experiment was performed in three replicates with 6 specimens in each replicate per group. These were exposed to three environmentally relevant levels of arsenic in separate aquaria (40-L capacity) which were $10 \mu \mathrm{g} \mathrm{L}^{-1}$ (permissible level in drinking water), $50 \mathrm{\mu g} \mathrm{L}^{-1}$ (acceptable level in India) and $500 \mu \mathrm{g} \mathrm{L}^{-1}$ (frequently reported high level arsenic content in groundwater) [31]. Sodium arsenite $\left(\mathrm{NaAsO}_{2}\right.$, CAS No. 7784-46-5; Loba-Chemie, Mumbai, India) was used for arsenic exposure as it is considered more toxic, soluble and mobile in water than arsenate [32]. The exposures were continued for 20 consecutive days. Arsenic contents of aquaria waters, determined by the process described above were regularly verified during the period of exposure to confirm the nominal levels $\left(10,50\right.$ and $\left.500 \mu \mathrm{gL}^{-1}\right)$ with less than $10 \%$ difference. Further, aquaria waters, under static removal system, were changed every day on regular basis to prevent accumulation of nitrogenous waste.

\section{Sampling of blood}

Blood sampling from fish specimens was done before and after exposure using heparinized tuberculin syringes fitted with 26 gauge needles after anaesthetizing them with benzocaine $\left(0.1 \mathrm{gl}^{-1}\right)$. Every time about $100 \mu$ blood was derived from each fish specimen through caudal vein puncture. The blood samples were then added to $95 \%$ ethanol in 1:5 ratio using Eppendorf tubes and kept at $4^{\circ} \mathrm{C}$ until used for DNA extraction. 


\section{DNA extraction and amplification}

DNA was extracted from the blood samples of pre- and post-exposure fish specimens of each experimental group separately following the technique adopted by Kumar et al. [16]. It was followed by polymerase chain reaction (PCR) using Taq DNA polymerase in a thermal cycler (Eppendorf, USA) for random amplification of polymorphic DNA (RAPD) following the method established by Atienzar et al. [33] with minor modifications. Briefly, PCR reactions were carried out for 40 cycles, each involving denaturation of template DNA for $1 \mathrm{~min}\left(94^{\circ} \mathrm{C}\right)$, annealing of primers for $1 \mathrm{~min}\left(48 \pm 2^{\circ} \mathrm{C}\right)$ and extension of new strand for $1 \mathrm{~min}\left(72^{\circ} \mathrm{C}\right)$ except initial denaturation for $3 \mathrm{~min}$ and final extension for $10 \mathrm{~min}$. Each reaction mixture $(25 \mu \mathrm{L})$ had $2.5 \mu \mathrm{L}$ polymerase buffer $(1 \mathrm{X}), 2.0 \mu \mathrm{L} \mathrm{MgCl}_{2}(2 \mathrm{mM}), 0.5 \mu \mathrm{L}$ dNTPs $(0.2 \mathrm{mM})$, $1.0 \mu \mathrm{LTaq}$ polymerse (1U), $1.0 \mu \mathrm{L}$ RAPD primer (10 pM) and $1.0 \mu \mathrm{L}$ genomic DNA (20 ng). PCR ingredients and RAPD primers were procured from Fermentas Life Sciences (USA) and Integrated DNA Technology (USA) respectively. $10 \mu \mathrm{L}$ sample of each amplified RAPD product was loaded in the sample well along with loading dye before electrophoresis.

A total of nineteen decamers (designed as OPA1 to OPA19; Table 2) were used as primers to amplify different loci and the polymorphism among amplified loci was detected upon electrophoretic mobility of the bands in $1.5 \%$ agarose gel. Electrophoresis was carried out for 5 hour at $40 \mathrm{~V}$ for proper development of bands followed by image capturing under UV light and its analysis using a gel documentation system (Vilber, E-BOXCX5).

\section{DNA analysis}

Alterations in DNA were identified according to the scored RAPD profiling data where the presence or absence of amplified fragments were marked as ' 1 ' or ' 0 ' and were scored as dominant or recessive alleles in a two allele system. The bands migrated to the same position with the same intensity were deemed to be homologous bands from the same allele as suggested by Lynch and Milligan [34]. Based on binary matrix, the total number of RAPD bands in all the experimental groups was calculated including the polymorphic ones. Using their allele frequencies and percentage of polymorphic loci (\%P), Nei's genetic distance and genetic variability between pairs of groups (population) were calculated with the help of POPGENE version 1.32 [35]. Finally, Un-weighted Pair Group Method with Arithmetic Means (UPGMA), as suggested by Sokal and Sneath [36], was used for clustering analysis, generating dendrogram. Genetic similarity (S) was calculated by the method suggested by Nei and Li [37] using the formula, $S=1 / 42 N A B /(N A+N B)$ where $N A B$ is the number of bands common in both the individuals $A$ and $B, N A$ is the number of bands in individual $A$ and $N B$ is the number of bands in individual $B$.

\section{Results}

RAPD bands were compared between pre- and post- exposure to arsenic for the same individual. Seven out of nineteen (about 37\%) decamer primers (OPA1, OPA3, OPA4, OPA5, OPA6, OPA8 and OPA9) were capable of producing strong and reproducible banding patterns in all samples tested, and the patterns 
were most distinguishable between the pre- and post- exposure samples. Altogether a total of 41 individual loci were amplified in pre- and post- exposure samples. The number of loci amplified in the preexposure specimens was 40 while specimens post- exposure to arsenic exhibited 39, 37, and 40 loci in $\mathrm{T}_{1}$, $T_{2}$, and $T_{3}$ groups respectively. The variation in the number of bands in different exposure levels appeared to be resulting from loss of few normal bands and/or gain of new bands upon arsenic exposure compared to pre- exposure state (Fig. 1). Some bands were polymorphic (marked in red arrows), showing their presence at different loci in various experimental groups. The band 1, generated by the primers OPA1 and OPA8, was found only in the pre-exposure sample but failed to appear after arsenic exposure. In contrast, bands 4, 6 and 7, generated by the primers OPA6, OPA1 and OPA4 or OPA9 respectively were observed only in post- exposure samples to high level of arsenic $\left(500 \mu \mathrm{gL}^{-1}\right)$. These loci, however, did not amplify in the pre- exposure as well as in the post- exposure to low levels of arsenic (10 and $\left.50 \mu \mathrm{gL}^{-1}\right)$, Indicating that high level exposure to arsenic had comparitively more severe effect than its low level exposures. Moreover, emergence of new bands exhibited a weak dose response relationship.

The UPGMA classification showed no intra-group variation but the banding patterns were found quite different between pre- and the post- exposure specimens. Moreover, the difference was more pronounced upon high level arsenic exposure $\left(T_{3}\right)$ than upon low level arsenic exposure $\left(T_{1}\right.$ and $\left.T_{2}\right)$. The dendrogram generated by Nei and Li's formula reflects the results of UPGMA cluster analysis (Fig. 2).

\section{Discussion}

The blood cell formation in fishes was extensively studied by Catton [38]. Although cell cycle dynamics and erythropoiesis have been well documented in mammalian system, less information is available with respect to fishes because of variation in their cell dynamics with temperature [39-40]. In Channa, maturation of erythrocytes takes around 20 days [41], as occurs in many other fishes [42-43]. The design of present study with an exposure period of 20 days at an almost constant temperature followed by blood sampling on the next day, therefore, is in accordance with the duration of blood cell formation in Channa.

The changes in the RAPD profile upon exposure to arsenic as occurred in the present work also reported with earlier studies in animals and plants [44-45], might have resulted from alterations in genomic DNA of fish. Arsenic has been shown to induce a variety of DNA alterations including DNA strand breaks, oxidation of bases, adduct formation and even DNA- protein cross links [46-48]. Since a single lesion in DNA can affect its amplification efficiency [49], arsenic induced alterations in DNA are likely to affect the kinetics of PCR events, leading to changes in the RAPD patterns. Alterations in the base sequences may lead to the accessibility of oligonucleotide primers to new priming sites in DNA, resulting in the emergence of new PCR products. As the probability of mutation in primer binding sites is unlikely, creation of new priming sites may results mainly from genomic rearrangements induced by arsenic. When new priming sites are used for amplification, it leads to appearance of new bands. In contrast, 
interaction between DNA polymerase and altered DNA may either cause complete cessation of DNA polymerization or slowing down of PCR reaction; consequently, few of the normal bands may disappear.

The present experiment, showing changes in the RAPD profiles of fish DNA upon exposure to arsenic, therefore, confirms the occurrence of DNA alterations induced by arsenic and also indicates gradual genomic instability with increase in the level of arsenic exposure. This finding in Channa punctatus exposed to sodium arsenite is consistent with similar observation in another Carassius auratus exposed to arsenic trioxide [16], suggesting RAPD-PCR assay is a reliable and sensitive method to detect arsenic induced genotoxicity at molecular level.

\section{Conclusion}

In the present study, RAPD-PCR method was found as a potential tool to show DNA alterations induced upon arsenic exposure and proved to be sensitive enough to unmask genotoxicity of arsenic at its various exposure levels in the freshwater fish Channa punctatus. In our results exposure to arsenic seems to induce changes in the oligonucleotide priming sites in DNA that produces new band(s) or results in loss of pre-existing band(s).

\section{Declarations}

\section{Ethical approval}

All procedures performed in this study approved by institutional ethical committee and each step was kept within the ethical norm suggested by CPCSEA (2006).

Consent to participate: not applicable

Consent for publication: not applicable

Availability of data and materials: The data generated and analyzed during this study are included in this article.

Competing interests: The authors declare that they have no competing interest.

Funding: Financial assistance for this study was provided by Department of Biotechnology, Government of India under DBT-PU-IPLS scheme (Sanction No.BT/PR4577/INF/22/149/2012).

Author's contribution: P. K. Khan contributed to the study conception and supervision. Material preparation, experimentation and analysis of results were performed by D. K. Jha, N. Yashvardhini and Saurav Bhattacharya. Kumar Sayrav estimated arsenic content in sample and aquaria water. Amod Kumar interpreted the results of RAPD analysis. The editing of the original draft, first prepared by D. K. Jha, was done by P. K. Khan. All authors read and approved the final manuscript. 


\section{Acknowledgment}

Financial assistance from Department of Biotechnology, Government of India under DBT-PU-IPLS scheme to P K Khan (Co-Principal Investigator) and Deepak Kumar Jha (Junior Research Fellow) is thankfully acknowledged.

\section{References}

1. IARC (2012) Arsenic, metals, fibres, and dusts. International Agency for Research on Cancer IARC monographs on the evaluation of carcinogenic risks to humans $100 \mathrm{C}, 1-526$

2. ATSDR (2017) Priority Substance List. United States Department for Health and Human Services, Atlanta, Georgia

3. Hassan M (2018) Arsenic in groundwater. CRS Press, Boca Raton

4. Minatel BC, Sage AP, Anderson C, Hubaux R, Marshall EA, Lam WL, Martinez VD (2018)

Environmental arsenic exposure: from genetic susceptibility to pathogenesis. Environ Int 112:183197

5. Podgorski J, Barg M (2020) Global threat of arsenic in groundwater. Science 368:845-850

6. Roy JS, Chatterjee D, Das N, Giri AK(2018) Substantial evidences indicate that inorganic arsenic is a genotoxic carcinogen: a review. Toxicol Res 34: 311-324

7. Ahmed MK, Habibullah-Al-Mamun M, Hossain MA, Arif M, Parvin E, Akter MS (2011) Assessing the genotoxic potentials of arsenic in Tilapia (Oreochromis mossambicus) using alkaline comet assay and micronucleus test. Chemosphere 84:143-149

8. Banerjee M, Banerjee N, Bhattacharjee P, Mondal D, Lythegoe PR, Martinez M (2013) High

9. arsenic in rice is associated with elevated genotoxic effects in humans. Sci Rep 3

10. Das S, Unni B, Bhattacharjee M, Wann S, Rao PG (2012) Toxicological effects of arsenic exposure in a freshwater teleost fish Channa punctatus. Afr J Biotech 11:4447-4454

11. Kesari VP, Kumar A, Khan PK (2012) Genotoxic potential of arsenic at its reference dose. Ecotoxicol Environ Saftey 8:126-131

12. Khan PK, Kesari VP, Kumar A (2013) Mouse micronucleus assay as a surrogate to assess genotoxic potential of arsenic at its human reference dose. Chemosphere 90:993-997

13. Williams K, Kubelik A, Livak K, Rafalsk iJ, Tinger S (1990) DNA polymorphisms amplified by arbitrary primers are useful as genetic markers. Nuc Acids Res 18:6531-6535

14. Abdel-Halim KY, Mona MH, Giesy JP, Osmen SR (2019) Cytotoxic effects of persistent organic pollutants on the freshwater snail (Lanistes carinatus) in Kafr El-Zayat, Egypt. Environ Monit Assess 191(11):699

15. Atienzar FA, Venier P, Jha AN, Depledge MH (2002) Evaluation of the random amplified polymorphic DNA (RAPD) assay for the detection of DNA damage and mutations. Mutat Res 521:151-163 
16. Atienzar FA, Jha AN (2006) The random amplified polymorphic DNA (RAPD) assay and elated techniques applied to genotoxicity and carcinogenesis studies: a critical review. Mutat Res 613:76102

17. Kumar A, Kesari VP, Alok AK, Kazim SN, Khan PK (2014) Assessment of arsenic-induced DNA damage in goldfish by a polymerase chain reaction-based technique using random amplified polymorphic DNA markers. Arch Environ Contam Toxicol 67:630-638

18. Noel S, Rath SK(2006) Randomly amplified polymorphic DNA as a tool for genotoxicity. an assessment. Toxicol and Ind Health 22: 267-275

19. Savva D (2000) The use of arbitrarily primed PCR (AP-PCR) fingerprinting detects exposure to genotoxic chemicals. Ecotoxicology 9:341-353

20. Yildirim N, Agar G (2016) Determination of genotoxic effect fipronil in Vicia faba using RAPD analysis. Toxicol Ind Health 32:1450-1455

21. Castaño A, Becerril C (2004) In vitro assessment of DNA damage after short- and longterm exposure to benzo[a]pyrene using RAPD and the RTG-2 fish cell line. Mutat Res552: 141-151

22. Rocco L, Frenzilli G, Zito G, Archimandritis A, Peluso C, Stingo V(2012) Genotoxic effects in fish induced by pharmacological agents present in the sewage of some Italian water-treatment plants. Environ Toxicol 27:18-25

23. Cambier S, Gonzalez P, Durrieu G, Bourdineaud JP(2010) Cadmium-induced genotoxicity in zebrafish at environmentally relevant doses. Ecotoxicol Environ Saftey 73: 312-319

24. Ahmad I, Ahmad, Masood (2015) Freshwater fish, Channa punctatus, as a model for pondi methalin genotoxicity testing: A new approach towards aquatic environmental contaminants. EnvironToxicol 31:1520-1529

25. Das S, Unni B, Bhattacharjee M, Wann S, Rao PG (2012) Toxicological effects of arsenic exposure in a freshwater teleost fish Channa punctatus. Afri J Biotec 11:4447-4454

26. Jha DK, Sayrav K, Mishra GP, Mishra BB, Kumari A, Kumar A (2019) Risk assessment of low arsenic exposure using biomarkers of oxidative and genotoxic stress in a piscine model. Ecotoxicology 28:669-679

27. Kumar A, Kesari VP, Khan PK (2013) Fish micronucleus assay to assess genotoxic potential of arsenic at its guideline exposure in aquatic environment. Biometals 26:337-334

28. Mehra S, Chadha P (2020) Naphthalene-2-sulfonate induced toxicity in blood cells of freshwater fish Channa punctatus using comet assay, micronucleus assay and ATIR-FTIR approach. Chemosphere 265:129-147

29. Pandey AK, Nagpure NS, trivedi SP (2018) Genotoxicity assessment of pesticide profenofos in freshwater fish Channa punctatus (Bloch) using comet assay and random amplified polymorphic DNA (RAPD). Chemosphere 211:316-323

30. Yadav KK, Trivedi SP (2009) Chromosomal aberrations in a fish, Channa punctata after in vivo exposure to three heavy metals. Mutat Res 678:7-12 
31. APHA (2017) Standard Methods for Examination of Water and Wastewater, 23rd edn. American Public Health Association, New York American Public Health Association, Washington, DC

32. WHO (2011) Guideline for Drinking-water Quality. World Health Organisation 4:315-318

33. He W, Meghraj M, Naidu R (2009) Toxicity of tri and pentavalent arsenic, alone and in combination, to the clado Daphnia carinata: the influence of microbial transformation in natural waters. Environ Geochem Health 31:13-141

34. Atienzar FA, Cordi B, Donkin ME, Evenden AJ, Jha AN, Depledge MH (2000) Comparision of ultraviolet-induced genotoxicity detected by random amplified polymorphic DNA with chlorophyll fluorescence and growth in a marine macroalgae, Palmaria pakmata. Aquatic Toxicol 50:1-12

35. Lynch M, Milligan BG (1994) Analysis of population genetic structure with RAPD markers. Mol Ecol 3:91-99

36. Yih LH, Lee TC (1999) Effects of exposure protocols on induction of kinetochore-plus and -minus micronuclei by arsenite in diploid human fibroblasts. Mutat Res 440:75-82

37. Sokal RR, Sneath PHA (1963) Principles of numerical taxonomy. Freeman, San Francisco, p 359

38. Nei M, Li WH(1979) Mathematical model for studying genetic variation in terms of restriction endonucleases. Proc Nat Acad Science USA 74: 5267-5273

39. Catton WT (1951) Blood cell formation in certain teleost fishes. Blood 6:39-60

40. Fange R (1986) Physiology of haematopoiesis. In: Nilson S, Holmgren S (eds) Fish physiology: recent advances. Croom Helm, London, pp 1-23

41. Nikinmaa M (1990) Vertebrate red blood cells. Adaptation of function to respiratory requirements. Springer, New York

42. Mahajan CL, Dheer JS (1979) cell types in the peripheral blood of an air-breathing fish Channa punctatus. J Fish Biol 14:481-487

43. Murad A, Houston AH (1992) Maturation of the goldfish (Carassius auratus) erythrocyte. Comp Biochem Physiol A 102:107-110

44. Dinnen RD, Tomlionson SM, Hart D, Chopra C, Heddle JA (1987) Application of micronucleus assay to the peripheral blood cells of the rainbow trout Salmo gairdneri. Can Tech Rep Fish Aquat Sci 1607:69-78

45. Lee YC, Yang VC, Wang TS (2007) Use of RAPD to detect sodium arsenite-induced DNA damage in human lymphoblastoid cells. Toxicology 239:108-115

46. Majumder B, Das S, Pal B, Biswas AK (2019) Evaluation of arsenic induced toxicity based on arsenic accumulation, translocation and its implications on physic-chemical changes and genomic instability in Indian rice cultivars. Ecotoxicology 29:13-24

47. Bau DT, Wang TS, Chung CH, Wang AS, Jan KY (2002) Oxidative DNA adducts and DNA-protein cross-links are the major DNA lesions induced by arsenite. Environ Health Pers 110:753-756

48. Mouron SA, Grillo CA, Dulout FN, Golijow CD (2006) Induction of DNA strand breaks, DNA protein crosslinks and sister chromatid exchanges by arsenite in a human lung cell line. Toxicol In Vitro 
20:279-285

49. Wang TS, Hsu TY, Chung CH, Wang AS, Bau DT, Jan KY (2001) Arsenic induced oxidative DNA adducts and DNAprotein cross-links in mammalian cells. Free Rad Biol Med 31:321-330

50. Sikorsky JA, Primerano DA, Fenger TW, Denvir J (2004) Effect of DNA damage on PCR amplification efficiency with the relative threshold cycle method. Biochem Biophy Res Commun 323:823-830

51. CPCSEA (2006) The Breeding and Experiments on Animals (Control and Supervision) Amendment Rule. Committee for the Purpose of Control and Supervision of Experiments on Animals. Ministry of Environment, Forests and Climate Change, Government of India

\section{Tables}

Table 1 Exposures levels of arsenic in the fish Channa punctatus

Experimental Exposure Level

\section{Groups}

$\left(\operatorname{\mu g~L^{-1})}\right.$
No of fish

Specimens

\author{
$\left(\mu g L^{-1}\right)$
}

$\mathrm{T} 1$

10

$6 \times 3$

$\mathrm{T} 2$

50

$6 \mathrm{x} 3$

T3

500

$6 \times 3$

Table 2 List of random oligonucleotide decamer primers used during RAPD assay

\begin{tabular}{|c|c|}
\hline Primer name & Nucleoti \\
\hline 1. OPA1 & 5'- TGC CGA GCT G- 3' \\
\hline 2. OPA2 & 5'- AGG GGT CTT G- 3' \\
\hline 3. ОРАЗ & 5'- GAA ACG GGT G- 3' \\
\hline 4. OPA4 & 5'- GTG ACG TAG G- 3' \\
\hline 5. OPA5 & 5'- GGG TAA CGC C- 3' \\
\hline
\end{tabular}




$\begin{array}{ll}\text { 6. OPA6 } & \text { 5'- AGC TCA CTG A- 3' } \\ \text { 7. OPA7 } & \text { 5'- AGT CGG GCT G- 3' } \\ \text { 8. OPA8 } & \text { 5'- AAT CGG GCT G- 3' } \\ \text { 9. OPG-09 } & \text { 5'- TCA CGT CCA C- 3' } \\ \text { 10. OPG-10 } & \text { 5'- CTG ACG TCA C- 3' } \\ \text { 11. OPG-11 } & \text { 5'- AGG GCC GTC T- 3' } \\ \text { 12. OPG-12 } & \text { 5'- TGC CCG TCG T- 3' } \\ \text { 13. OPG-13 } & \text { 5'- CAG CTC ACG A- 3' } \\ \text { 14. OPG-14 } & \text { 5'- GGA TGA GAC C- 3' } \\ \text { 15. OPG-15 } & \text { 5'- ACT GGG ACT C- 3' } \\ \text { 16. OPG-16 } & \text { 5'- AGC GTC CTC C- 3' } \\ \text { 17. OPG-17 } & \text { 5'- ACG ACC GAC A- 3' }\end{array}$

18. OPG-18 5'- GGC TCA TGT G- 3'
19. OPG-19 5'- GTC AGG GCA A- 3'

\section{Figures}




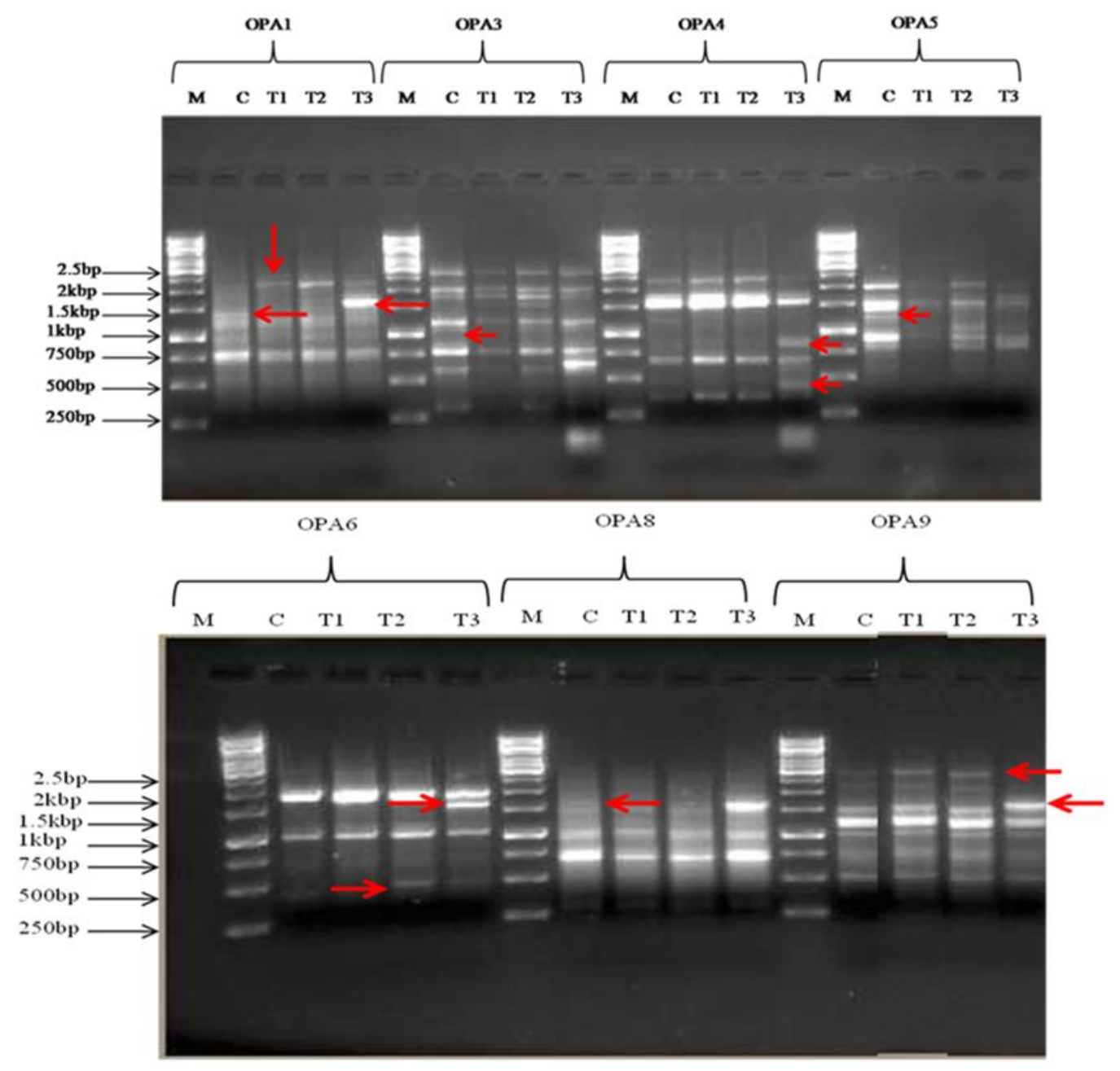

Figure 1

RAPD profiles of genomic DNA from the same specimen of Channa punctatus before (C) and after exposure to arsenic at three different levels (T1: $10 \mu \mathrm{gL}-1, \mathrm{~T} 2: 50 \mu \mathrm{gL}-1, \mathrm{~T} 1: 500 \mu \mathrm{gL}-1)$. The polymorphic bands are shown with red arrow. 


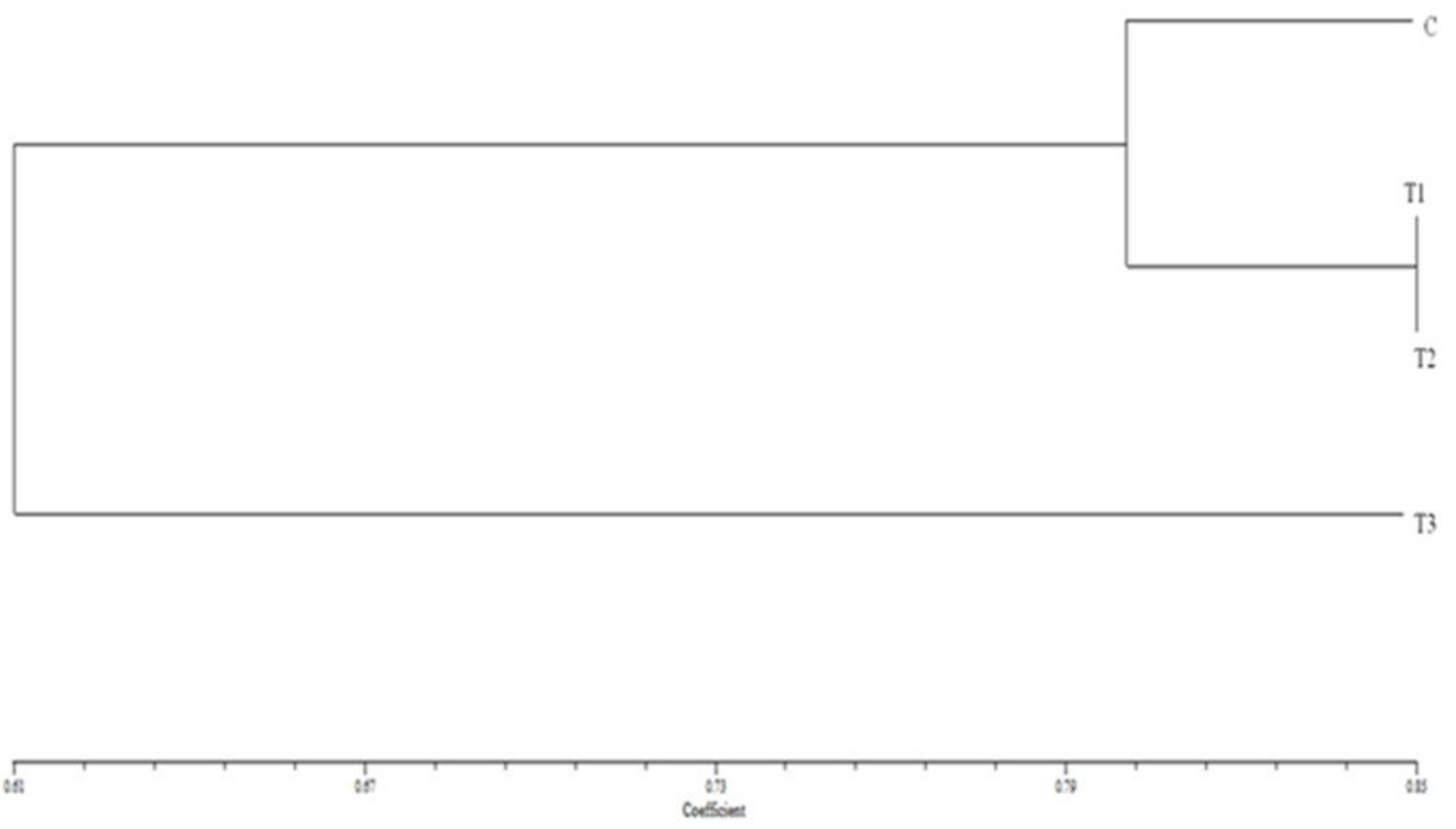

\section{Figure 2}

UPGMA dendrogram for cluster analysis of RAPD band profiles of the fish specimen of Channa punctatus before ( $C$ ) and after exposure to arsenic at three different levels (T1: $10 \mu g \mathrm{~L}-1, \mathrm{~T} 2: 50 \mu \mathrm{gL}-1$ and T1: $500 \mu \mathrm{gL}-1)$ using Jacard's coefficient of similarity. 